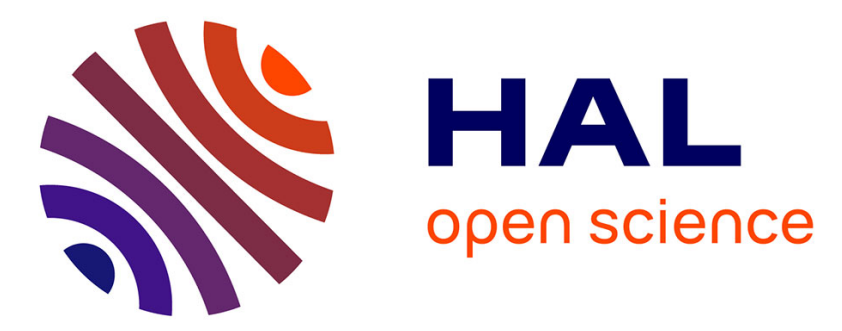

\title{
Late Palaeozoic-Early Mesozoic geological features of South China: Response to the Indosinian collision events in Southeast Asia
}

\author{
Liangshu S. Shu, Michel Faure, Bo Wang, Xinmin Zhou, Biao Song
}

\section{- To cite this version:}

Liangshu S. Shu, Michel Faure, Bo Wang, Xinmin Zhou, Biao Song. Late Palaeozoic-Early Mesozoic geological features of South China: Response to the Indosinian collision events in Southeast Asia. Comptes Rendus Géoscience, 2008, 340, pp.151-165. insu-00202662

\section{HAL Id: insu-00202662}

https://hal-insu.archives-ouvertes.fr/insu-00202662

Submitted on 7 Jan 2008

HAL is a multi-disciplinary open access archive for the deposit and dissemination of scientific research documents, whether they are published or not. The documents may come from teaching and research institutions in France or abroad, or from public or private research centers.
L'archive ouverte pluridisciplinaire HAL, est destinée au dépôt et à la diffusion de documents scientifiques de niveau recherche, publiés ou non, émanant des établissements d'enseignement et de recherche français ou étrangers, des laboratoires publics ou privés. 


\title{
Late Palaeozoic-Early Mesozoic geological features of South China: Response to the Indosinian collision events in Southeast Asia
}

\section{Les traits géologiques de la Chine du Sud à la fin du Paléozoïque et au début du Mésozoïque : réponse aux collisions indosiniennes en Asie du Sud- Est}

\author{
Liangshu Shu ${ }^{a}$, Michel Faure ${ }^{b}$, Bo Wang ${ }^{a}$, Xinmin Zhou $^{a}$ and Biao Song \\ ${ }^{a}$ State Key Laboratory for Mineral Deposits Research and Department of Earth Sciences, \\ Nanjing University, 210093 Nanjing, PR China \\ ${ }^{\mathrm{b}}$ Institut des sciences de la terre d'Orleans, université d'Orléans, 45067 Orléans cedex 2, \\ France \\ ${ }^{\mathrm{c}}$ Center of Iron-Probe in Beijing, 26 Baiwanzhuang road, Fuwai, 100037 Beijing, PR China
}

\begin{abstract}
This paper provides some new evidences on stratigraphic sequence, zircon SHRIMP dating from ophiolite, granitoids, and fold-and-thrust tectonic styles in the South China Block (SCB). Stratigraphic studies suggest that the eastern and central parts of the SCB show a SWdipping palaeoslope framework during the Late Palaeozoic-Early Mesozoic. These areas were not in a deep-sea environment, but in a shallow-sea or littoral one. Coeval volcanic rocks are missing. Deep-water deposits and submarine volcanism only took place in the western part of the SCB. The three ophiolitic mélanges of the eastern SCB formed in the Neoproterozoic, but not in the Permian or the Triassic. The sedimentary rocks associated with the Neoproterozoic oceanic relics contain abundant Proterozoic acritarchs, but no radiolarians. The Early Mesozoic granitoids (235-205 Ma) belong to the post-collision peraluminous S-type granites; they are widely exposed in the central-western SCB, and rare in the eastern SCB. The foldand-thrust belt developed in the eastern SCB shows a top-to-the-south displacement, whereas the Xuefengshan Belt of central SCB indicates a north- or northwest-directed shearing. The geodynamic settings of the different parts of the SCB during the Triassic are discussed.
\end{abstract}




\section{Résumé}

Cet article fournit des données nouvelles sur le bloc Chine du Sud (BSC) en matière de séquence stratigraphique, de datation SHRIMP sur zircon dans des ophiolites et granitoïdes et à propos de styles de déformation tectonique. Des études stratigraphiques suggèrent que les parties orientale et centrale du BSC correspondaient à une paléopente à pendage sud-ouest pendant la période allant de la fin du Paléozoïque au début du Mésozoïque. L'environnement n'était pas du type mer profonde, mais de type peu profond ou littoral, et le volcanisme en était absent. Les sédiments profonds et le volcanisme sous-marin ne concernent que la partie occidentale de la Chine du Sud. Les trois mélanges ophiolitiques présents dans la partie orientale se sont formés au Néoprotérozoïque, et nullement au Permien ou au Trias. Les roches sédimentaires associées à ces reliques de l'océan protérozoïque contiennent d'abondants Acritarches protérozoïques, mais pas de Radiolaires. Les granites du début du Mésozoïque (235-205 Ma) appartiennent à la catégorie des granites hyperalumineux postcollisionnels de type $\mathrm{S}$ et sont largement représentés dans la partie centre-occidentale du BSC, rarement dans la partie orientale. La chaîne plissée et chevauchante qui se développe dans l'Est de la Chine du Sud montre une vergence vers le sud, tandis que la ceinture chevauchante de Xuefengshan indique un cisaillement vers le nord ou le nord-ouest. Le cadre géodynamique au Trias des différentes parties de la Chine du Sud est discuté.

Keywords: Stratigraphy; Deformation; Ophiolite; Granitoids; Late Palaeozoic-Early Mesozoic; Indosinian event; South China

Mots clés: Stratigraphie; Déformation; Ophiolite; Fin du Paléozoïque-début du Mésozoïque; Événement indosinien; Chine du Sud

\section{Introduction}

Several previous researchers considered that the South China Block (SCB), alike Southeast Asia, experienced a strong Permian to Triassic deformation and magmatism referred to as the "Indosinian event" [4], [9], [16] and [33]. This event is well documented in Vietnam and many places of Southeast Asia. For example, zircon from ophiolites and muscovite from mylonites in northern Vietnam yielded $\mathrm{U}-\mathrm{Pb}$ and ${ }^{40} \mathrm{Ar} /{ }^{39} \mathrm{Ar}$ ages of $258-245 \mathrm{Ma}$ [1], [11], [19], [21], [29], [30] and [34]. In northern Vietnam, the Song Ma ophiolitic suture developed around 250-240 Ma separates the South China Block (SCB) from the Indochina Block [1].

In South China, the Indosinian event is attested to by the development of a regional unconformity between the Middle and the Late Triassic $\left(T_{2}\right.$ and $\left.T_{3}\right)$. Sometimes the Early Jurassic $\left(\mathrm{J}_{1}\right)$ directly overlies older rocks by an angular unconformity [47] and [60]. Early Triassic brittle and ductile fabrics and folds are also identified [5] and [44], and voluminous granitic intrusions [7], [25], [50] and [68] also argue for an Indosinian event.

During the last two decades, two distinct geodynamic models have been postulated for the Indosinian tectonic evolution of the SCB. One model proposes that the Indosinian event resulted from the subduction of an ancient oceanic crust [11], [15] and [37]. Recently, some geologists argued for a model involving Late Permian to Early Triassic oceans and island-arc collisions to interpret the formation of the Early Mesozoic foreland fold-and-thrust belt [56]; they also suggested a flat-slab subduction hypothesis [26] for the development of the 1300$\mathrm{km}$-wide intracontinental orogen. However, the collision model has been challenged by the 
absence of any Early Mesozoic deep-sea deposits, ophiolite and island-arc volcanic rocks in the eastern and central parts of the SCB [45] and [53]. Other interpretations put forward an Early Mesozoic intracontinental extension as the dominant mechanism in response to an upwelling of asthenosphere, which acted as a driver for the geological evolution of the SCB and adjacent areas [10], [46] and [51]. These models may explain the generation of S-type granites with high initial strontium ratios [68] that are widespread in the central SCB (Nanling area).

Furthermore, the southwestern and northern boundaries of SCB correspond to the Song MaMenglian and the Qinling-Dabie belts, respectively (Fig. 1). These two orogens separate the SCB from Indochina to the south and from the North China Block (NCB) to the north. There, Permian and Triassic deformations are well acknowledged, and it is tempting to relate the Early Mesozoic features of SCB to the tectonics that took place along those two major boundaries.

The tectonic nature of the Indosinian movement in the SCB can be partly understood by the analysis of two key geological aspects: (1) the Late Palaeozoic to Early Mesozoic sedimentary environment, and (2) the assessment of the age of the so-called Late Palaeozoic radiolarianbearing ophiolitic rocks, which have been poorly discussed since the 1990s. In this paper, we present new evidences on stratigraphic sequence, geochronology for ophiolite and granitoids, and deformation style. These geological facts enable us to understand better the Late Palaeozoic to Early Mesozoic tectonic evolution of the SCB.

\section{Geological setting}

The SCB can be divided into western, central and eastern parts by the Jishou-Guilin fault (Fig. 1, 5) and the Shaoxing-Pingxiang-Chenzhou-Yulin fault (Fig. 1,1). In the SCB, the Indosinian event is widespread in the southern part of the Qinling-Dabie belt and in its western part, along the Song Ma-Menglian suture, which extends from northern Vietnam to Southwest China (inset in Fig. 1). Evidence for the Indosinian event includes a Late Triassic regional unconformity, folding, and thrusting of the Pre-Triassic strata and granite emplacement. Recent zircon U-Pb SHRIMP dating suggests that Indosinian granitoids in the SCB formed in two main periods, namely at 245-230 Ma and 218-210 Ma, respectively [35], [36] and [55]. In the Chenzhou-Linwu segment of the Shaoxing-Pingxiang-Yulin fault (Fig. 1,1), between the Yangtze and Cathaysian blocks, alkaline-subalkaline basaltic lavas and related mafic dikes were recently identified, dated from $175 \mathrm{Ma}, 125-150 \mathrm{Ma}$, and 80-95 Ma, respectively [52]; their geochemical features indicate a tectonic setting of intracontinental lithospheric extension during the Late Mesozoic (175-80 Ma).

Our study focuses mainly on the eastern and central part of the SCB. The NE-SW-trending Shaoxing-Jiangshan-Pingxiang-Chenzhou-Yulin zone documents a two-phase event between the central part (also called the Yangtze Block) and the eastern one (also called the Cathaysian Block; Fig. 2). The first one is a Neoproterozoic collision that took place between the Jiangnan volcanic arc and the Cathaysian Block. It is constrained by ophiolites and granodiorites dated from around $900 \mathrm{Ma}$ [45]. The second event occurred between the Yangtze and the Cathaysian blocks during the Early Palaeozoic period, as indicated by an angular unconformity of Late Devonian sandstone upon Ordovician phyllite, and also by granite dated around $445 \mathrm{Ma}$ and $430 \mathrm{Ma}$ on zircon by LA-ICPMS U-Pb [46]. Muscovite yields ${ }^{40} \mathrm{Ar} /{ }^{39} \mathrm{Ar}$ ages at ca $420 \mathrm{Ma}$, an age interpreted as that of a ductile shearing [45]. The pre-Devonian tectonics has been reworked by polyphase tectonic events such as Early 
Triassic (Indosinian) folding and Cretaceous deformation related to the emplacement of Yanshanian granitic plutons. The Late Devonian to Early Triassic strata in the eastern SCB present a continuous sequence, comprising mainly limestone, dolomite, marlite, sandstone, siltstone and mudstone [8], [17], [63] and [67].

\section{Stratigraphic sequence}

In order to constrain the stratigraphic features and the evolution of the palaeoenvironment during the Late Palaeozoic to Early Mesozoic interval, we studied six lithostratigraphic successions in the eastern SCB (Fig. 3; their locations are shown in Fig. 2). As described by Xiao and He [56], a Late Carboniferous to Middle Triassic southeast-directed palaeoslope might be suggested from southeastward strata thickening (Fig. 3, 1, 3, 5). Nevertheless, lithological features and fossil assemblages in the Upper Carboniferous-Lower Permian and Middle Triassic series show a palaeoenvironmental evolution from shallow sea to littoral and then to swamp land. In contrast, neither deep-sea turbidite nor coeval mafic volcanic or volcanoclastic rocks are found. In the study area, three coal-bearing layers developed in the Lower Permian (Fig. 3, 2), Upper Permian (Fig. 3, 1, 4, 5, 6) and Upper Triassic series. Six land-facies layers with plant fossils occurred in the Lower Permian (Fig. 3, 5, 6), Middle Permian (Fig. 3, 2, 4, 5, 6), Upper Permian (Fig. 3, 1, 3), Lower Triassic (Fig. 3, 5, 6), Middle Triassic (Fig. 3, 3, 4, 5, 6) and Upper Triassic (Fig. 3, 1, 3, 4, 5, 6). In most of the areas of the $\mathrm{SCB}$, numerous shallow sea animal fossils, such as Brachiopoda, Pelecypoda, Cephalopoda, Fusulina and Coral, and land plant fossils, such as Pecopteris and Gigantopteris, are well preserved. These remnants indicate a palaeogeographic evolution from continental shelf to littoral and then to swamp land environments.

In the SCB, the lower part of the Upper Triassic sedimentary series consists of red coloured conglomerate, coarse sandstone, quartz sandstone, carbonaceous siltstone, and coal layers, with a total thickness ranging from 300 to $600 \mathrm{~m}$. These coarse clastic rocks unconformably cover folded Carboniferous-Permian and Early Triassic rocks, demonstrating the Indosinian tectonism. The stratigraphic features in the central SCB are similar to those of the eastern $\mathrm{SCB}$, indicating a similar palaeogeographic environment. However, in the western SCB, for instance in western Yunnan, Triassic basalt, andesite, some rhyolite, and chert-bearing turbidite are widely distributed, suggesting an environment close to an active continental margin. They will be described in the later sections.

\section{Geochronological constraint on ophiolite}

Three NE-SW-trending ophiolitic belts crop out in the SCB, namely, the Dexing-Shexian zone to the northwest, the Shaoxing-Jiangshan-Pingxiang zone in the centre, and the Zhenghe-Dapu zone to the southeast (Fig. 2). These ophiolitic mélanges comprise various relics of serpentinized peridotite, orthopyroxenite, sheared gabbro, diabase, basalt, and chert. They are associated with turbidites. The rocks surrounding the ophiolites are the Proterozoic greenschist facies turbidite, basalt-andesite and volcanoclastic rocks. The Shiershan granite that crosscuts the ophiolitic mélange, yielded a zircon $\mathrm{U}-\mathrm{Pb}$ age of $825 \pm 3 \mathrm{Ma}$ [28], providing an upper limit of the ophiolitic mélange. Unmetamorphosed and undeformed Neoproterozoic Sinian terrigenous rocks (conglomerate, coarse-grained sandstone, mudstone) unconformably overlie the Proterozoic metamorphic rocks [38], [39] and [43].

Geochronological data on the ophiolitic mafic rocks have been carried out in the DexingShexian zone (Fig. 2, 3). The results include: 
- $968 \pm 23$ Ma for the plagioclasite of Zhangshudun (SHRIMP zircon U-Pb [24])

- $930 \pm 34 \mathrm{Ma}$ for the ophiolite of Xiwan (Sm-Nd isochron [57])

- $1034 \pm 24 \mathrm{Ma}$ for the ophiolitic gabbro and the basalt of Zhangshudun (Sm-Nd isochron [2])

- $1024 \pm 30 \mathrm{Ma}$ for the ophiolitic gabbro of Shexian (Sm-Nd isochron [66])

- $866 \pm 14 \mathrm{Ma}$ for glaucophane grains from blueschist in Xiwan (K-Ar [42]).

The date of the high-pressure metamorphism indicates a Neoproterozoic age for the closure of the oceanic area and the subsequent collision representative of the Jiangnan orogen.

Several geochronological ages on the ophiolitic rocks of the Shaoxing-Jiangshan-Pingxiang zone have also been documented. These data mostly concentrate around 830-860 Ma; e.g., a $\mathrm{K}-\mathrm{Ar}$ age of $880 \pm 10 \mathrm{Ma}$ of amphibole in a diorite [67]), a ${ }^{40} \mathrm{Ar} /{ }^{39} \mathrm{Ar}$ plateau age of $845 \pm 10 \mathrm{Ma}$ of amphibole in a pyroxenite [18]), and a ${ }^{40} \mathrm{Ar} /{ }^{39} \mathrm{Ar}$ plateau age of $832 \pm 7 \mathrm{Ma}$ of amphibole in an amphibolite [20]). Recently, Shu et al. [45] reported a SHRIMP zircon U-Pb age of $858 \pm 11 \mathrm{Ma}$ from the Huaquan gabbro block included in the ophiolitic mélange.

The Zhenghe-Dapu ophiolite was poorly studied, thus resulting in a confusing interpretation of its tectonic setting since the 1980s. This zone has been previously considered as an Early Palaeozoic suture zone. However, this viewpoint conflicts with the Early Palaeozoic shallowwater sedimentary rocks characterized by ripple marks and Trilobite-Brachiopoda fossils [45]. Two types of basaltic rock coexisting in this zone are identified [49]; one is of the calcalkaline type with geochemical features similar to that of IAB, dated from $853 \pm 4 \mathrm{Ma}$ by SHRIMP zircon U-Pb for the Jian-Ou pillow basalt [41], the other belongs to a tholeiitic rock with subalkaline characteristics [49]. Zircon single grains from a fresh subalkaline basalt sample (No. 452) of Zhenghe (Fig. 2) were recently dated in the Centre of Iron Probe in Beijing. The analytic results are listed in Table 1. The representative cathodoluminescence images of zircon grains from the basalt are shown in Fig. 4. Almost all of the analytical spots are concordant; they gave a mean weighted ${ }^{206} \mathrm{~Pb} /{ }^{238} \mathrm{U}$ age of $795 \pm 7$ Ma with MSWD of 2.90 (Fig. 5). The age $795 \pm 7 \mathrm{Ma}$ is younger than that of the Shaoxing-Jiangshan ophiolitic zone (830-860 Ma), but it is closely consistent with the one of $818 \pm 9 \mathrm{Ma}$ obtained by SHRIMP zircon $\mathrm{U}-\mathrm{Pb}$ on rifting-related rhyolite to the west of Zhenghe [23]. Here, we preliminarily interpret both $795 \pm 7 \mathrm{Ma}$ and $818 \pm 9 \mathrm{Ma}$ as the post-collision rifting age likely related to the break-up of Rodinia.

The ages of three ophiolitic zones reveal a migration trend of ancient oceanic crust, from the northwest (930-1030 Ma) toward the southeast (830-860 Ma). We interpret these three Neoproterozoic ophiolites in terms of oceanic crust and back-arc basin and polyphase continental collision [45]. The Zhenghe area documents a Neoproterozoic rifting event dated back to $800-820 \mathrm{Ma}$. Thus, it is concluded that the ophiolitic mélange zones in the eastern SCB were generated in the Neoproterozoic rather than in the Late Palaeozoic to Early Mesozoic, as claimed by Xiao and He [56]. 


\section{Checking on the radiolarian-bearing ophiolite}

Since Zhao et al. [64] reported Carboniferous-Late Permian radiolarians in siliceous rocks formerly defined as Proterozoic in the eastern Jiangnan belt, many researchers accepted the model of a Late Palaeozoic to Early Mesozoic oceanic basin in South China [47], [56] and [61]. In this model, both the Dexin-Shexian and the Shaoxing-Jiangshan ophiolitic zones represent two oceanic areas separating the Yangtze, Lower Yangtze and Cathaysia blocks from Late Permian to Early Triassic. Then, two mélange zones separating the three blocks formed during the Middle Triassic and the Late Jurassic [56].

Between 1998 and 2002, more than 300 cherts were sampled in the same points, where radiolarians were reported [64]. A total of 191 chert and 115 siliceous slate samples were analyzed by Prof. Wang Yujing in the Micropaleontology Laboratory of the Nanjing Institute of Geology and Palaeontology. No radiolarian fossils were found in these rocks, but by contrast, some samples yielded Mesoproterozoic and Neoproterozoic acritarchs [54] and [59]. Thus, this micropaleontology checking and the available geochronological data of the ophiolites from the mélanges do not support the conclusion of "a Late Palaeozoic to Mesozoic deep sea" in the SCB.

\section{Indosinian granitic magmatism}

In the SCB, the Indosinian event is also characterized by a widespread Early Mesozoic magmatism. Granitoids, dated back to 245-210 Ma, are distributed in the southern Hunan, northern Guangdong, central Hainan, western Yunnan Provinces and Southeast Guangxi regions, which totally cover more than $15,000 \mathrm{~km}^{2}$. The pluton ages cluster in two groups, indicating a complex petrogenesis in the SCB. The granitoids, dated back to 245 and $230 \mathrm{Ma}$ with $\mathrm{A} / \mathrm{CNK}=1.0$ to 1.1 , reflect an affinity to I-type granites, which were generated from mixing sources of pelitic and basaltic rocks, with an insignificant addition of newly mantlederived magma [55]. The granitoids dated from 218-210 Ma contain high aluminous minerals, such as muscovite, cordierite and tourmaline with $\mathrm{A} / \mathrm{CNKN}>1.1$. Most of Indosinian peraluminous granitoids, similar to S-type granites [35], [36] and [55], are considered as post-collisional plutons [68].

In the eastern SCB, Permian-Early Triassic granites are rare and contemporaneous volcanic rocks are absent. However, in the western SCB, the Permian-Triassic intermediate-basic volcanic rocks, intercalated with some rhyolites with a thickness of $7400 \mathrm{~m}$, widely crop out in the areas of Deqin-Weixi and Yunxian-Jinghong, along the Langcangjiang River (northwestern Yunnan) [62] (Fig. 1). There, Permian-Triassic turbidites containing chert layers are also well developed. Indosinian ophiolites associated with turbidites were found recently in the Changning-Menglian area in western Yunnan [65] (Fig. 1).

In the central SCB, the Indosinian granites are well developed. In the Nanling region, three east-west-trending Indosinian plutonic zones intrude in folded and sheared Late Palaeozoic rocks (Fig. 2), each of which being about $30-40 \mathrm{~km}$ wide. The first plutonic zone, the Qitianling-Jiufengshan zone, is located between $\mathrm{N} 25^{\circ} 20^{\prime}$ and $\mathrm{N} 25^{\circ} 35^{\prime}$, and is marked by the occurrence of Indosinian S-type peraluminous cordierite-bearing granites (e.g., the Zhuguangshan pluton). The second one is the Dadongshan-Guidong granitic zone (N2430'$\mathrm{N} 25^{\circ} 00^{\prime}$ ), where the Guidong pluton, associated with large-scale $\mathrm{W}, \mathrm{Sn}$, and U ore deposits, is dated back to $228 \pm 3 \mathrm{Ma}, 226 \pm 9 \mathrm{Ma}, 225 \pm 2 \mathrm{Ma}$ by LA-ICPMS zircon U-Pb [55] and [68]. The third one is the Fugang-Xinfengjiang granitic zone $\left(\mathrm{N} 23^{\circ} 30^{\prime}-\mathrm{N} 24^{\circ} 10^{\prime}\right)$ that hosts 
numerous $\mathrm{W}, \mathrm{Sn}$ and $\mathrm{U}$ ore deposits. The geophysical data show that the three granitic zones correspond exactly to the areas of mantle lithosphere uplifting and continental crust thinning. It is worth noting that some Indosinian granites underwent significant ductile shearing associated with their emplacement in an extensional setting, as observed in the Wugongshan (central Jiangxi Province) [5] and the Xuefengshan [55].

In the western SCB, available geochemical data revealed that the granitoids with an affinity of I-type granite might be genetically related to the Early-Middle Triassic collision (258 to $243 \mathrm{Ma}$ ) along the Song Ma suture (northern Vietnam) between the SCB and the IB [1]. The granitic plutons in the southwestern part of the SCB yielded zircon U-Pb SHRIMP ages, ranging from 245 to $230 \mathrm{Ma}$ [35], [36] and [55], and ${ }^{40} \mathrm{Ar} /{ }^{39} \mathrm{Ar}$ muscovite ages of $229 \pm 3 \mathrm{Ma}$ [40].

\section{Indosinian deformation fabrics}

The Early Triassic deformation is obvious in the SCB. Almost all pre-Late Triassic strata were involved into various-scale folding, somewhat comparable to Jura-type folds. Largescale folds generally show east-west-trending axial planes in the eastern SCB, and northeasttrending axial planes in the central SCB. Folding is associated with the development of thrust sheets. A regional-scale unconformity occurred between the Upper Triassic Anyuan Formation, composed of coal-bearing coarse clastic rocks, and the underlying PermianCarboniferous bioclastic limestone, providing an indicator of the upper limit of the folding and thrusting. A typical Indosinian deformation can be observed in the Jiulingshan and Xuefengshan in the eastern and central parts of SCB, respectively.

The east-west-trending Jiulingshan, $120-140-\mathrm{km}$ wide and $250-\mathrm{km}$ long, is a part of the Neoproterozoic Jiangnan orogenic belt. Stratigraphically, it comprises the Mesoproterozoic Jiuling Group, Neoproterozoic Banxi Group (slate and phyllite), Palaeozoic shallow marine sequences intercalated with plant-fossil-bearing clastic rocks and Mesozoic terrigenous deposits. In the northern Jiulingshan, three angular unconformities were observed between the Neoproterozoic Banxi Group and Sinian tillites and carbonates, between the Silurian shales and the Upper Devonian coarse clastic terrigenous rocks, and between the Permian limestones and the Upper Triassic clastic rocks. Folds are common structures, including centimetre- to decimetre-scale recumbent folds with gentle axial plane dipping to the NNW, folds with subhorizontal axes trending N60E, subvertical fan-shaped crenulation cleavage [27].

The inner part of the Jiulingshan is occupied by Neoproterozoic metamorphic rocks and granodiorites, dated back to $828 \pm 8 \mathrm{Ma}$ by SHRIMP zircon U-Pb [41]. Its southern and northern slopes are composed of east-west-trending fold-and-thrust slabs. The cross section from the southern slope of the Jiulingshan to the Pingxiang basin shows north-dipping reverse faults and thrust sheets composed of Late Palaeozoic carbonates and Neoproterozoic greenschist-facies metamorphic rocks (Fig. 6). Numerous klippes of Neoproterozoic phyllite with a top-to-the-south sense of movement crop out in this section. In several places, the Middle Carboniferous-Lower Permian limestone series are overthrust southward by Neoproterozoic metamorphic blocks along low-angle fault planes. These tectonic contacts are unconformably overlain by Lower Cretaceous conglomerates (Fig. 6). Only cataclasis and fracturing occur at the interface between the thrust blocks and the Upper Palaeozoic rocks [6] and [27]. Collapse structures develop on both slopes of the Jiulingshan, namely, north-dipping normal fault on the northern slope and south-dipping normal fault on the southern slope, respectively. Proterozoic metamorphic slabs glided to the north upon the Palaeozoic limestone 
of the Xiushui basin. The down-sliding slabs and normal faults cut the folded and sheared slabs, indicating that the collapse is younger than the folding-and-thrusting event.

The Xuefengshan (Fig. 2) is a northeast-trending fold-and-thrust belt, with a width of 80 $120 \mathrm{~km}$ and length of more than $200 \mathrm{~km}$ [13]. Its lithological assemblage is similar to that found in the Jiulingshan. The Xuefengshan fold-and-thrust belt comprises a series of southeast-dipping thrust sheets, with related drag folds and large-scale low-angle décollement faults dipping to the southeast. All the structures record a top-to-the-northwest displacement of a multilayer thrust system, with an evolution from thick-skin to thin-skin structures, from the southeast to the northwest (section C, D in Fig. 2) [58]. In the southeastern side of Xuefengshan, a thick Proterozoic metamorphic series was involved in the folding and thrusting, and to the northwest, the fold-and-thrust sequence involves Late Palaeozoic to Triassic strata. In the southeastern slope of the Xuefengshan, a few northwest-dipping thrusts constitute, together with those on the northwestern slope, a tenth of kilometre-scale fan-type structure [53] (section C, D in Fig. 2). Different from those of the Jiulingshan, the Palaeozoic rocks of the Xuefengshan experienced a ductile shearing, the timing of which is constrained between the Middle Triassic to Early Jurassic (244-195 Ma) by the ${ }^{40} \mathrm{Ar}-{ }^{39} \mathrm{Ar}$ method on muscovite grains of mylonitic rocks [53]. Peraluminous granites that intruded into the folded and sheared Late Palaeozoic rocks yield zircon U-Pb SHRIMP ages of 220-244 Ma [53].

In southwestern Fujian, in the central part of the SCB, a fold-and-thrust structure, with a SEEdipping axial plane and top-to-the-NWW thrusts, involves Permian, Carboniferous, and Middle Triassic series, but no Late Triassic ones, indicating a Middle Triassic movement (section A, B in Fig. 2) [14].

\section{Discussion}

\subsection{Late Palaeozoic to Early Mesozoic palaeogeography}

As mentioned above, during the Permian-Triassic interval, three coal-bearing layers (in $\mathrm{P}_{1}$, $\mathrm{P}_{3}$, and $\mathrm{T}_{3}$ ) and six plant-bearing continental intercalations (in $\mathrm{P}_{1}, \mathrm{P}_{2}, \mathrm{P}_{3}, \mathrm{~T}_{1}, \mathrm{~T}_{2}$, and $\mathrm{T}_{3}$ ) were developed in the eastern SCB and the Pingxiang area of the central SCB. These areas correspond to a shallow-sea environment with a south-dipping slope and experienced a palaeogeographic evolution from shallow-sea to littoral and then to swampland conditions. There is no palaeontological or sedimentological evidence to support the existence of a Late Palaeozoic to Early Mesozoic ocean. The ophiolitic mélanges in the eastern SCB were accurately dated back to the Neoproterozoic. Therefore, it is impossible to argue that the welding of central and eastern SCB amalgamated by subduction during the Late Palaeozoic and the Early Mesozoic.

Toward the west, the Upper Palaeozoic to Lower Mesozoic sequences in the Xuefengshan and the southern part of the Hunan Province in the central SCB are similar to those of the eastern SCB. Further westward to southwestern Guizhou, northwestern Guangxi, and the Yunnan regions of the western SCB, the Upper Palaeozoic-Lower Mesozoic sequences are characterized by carbonate, chert, turbidite and volcanic rocks, with a thickness of $3-10 \mathrm{~km}$. These rock assemblages are quite distinct from those found in the central and eastern SCB. For example, in southwestern Guizhou, the Lower-Middle Triassic series comprises 3-5-kmthick turbidite and limestone; in the northwestern Guangxi, the Permian rocks are composed of carbonate and chert, and the Lower-Middle Triassic series consist of limestone, sandstonemudstone intercalations with intermediate-basic volcanic rocks. In western Yunnan, the 
Permian submarine spilite-keratophyre series, containing ultramafic/mafic blocks, with a thickness of 5-10 km, and the Lower-Middle Triassic sandstone/mudstone, with a thickness of $5 \mathrm{~km}$, are widely developed. These observations indicate an evolution from a volcanismfree shallow sea in the eastern and central parts of the SCB to a bathyal and then abyssal sea environment, coeval with volcanism during the Late Palaeozoic and the Early Mesozoic in the western part of the SCB.

\subsection{Tectonic differences among the three parts of the SCB during the Indosinian event}

There are some compositional and tectonic differences among the eastern, central, and western parts of the SCB. In the eastern SCB, the response to the Indosinian event is shown by the regional Late Triassic-Early Jurassic angular unconformity, the large-scale fold-thrust slabs with a top-to-the-south sense of shear and the small-scale Middle-Late Triassic S-type granites. However, there is no evidence of the Late Permian-Early Triassic subduction and collision event within the eastern SCB because of the absence of volcanic rock, I-type granite, and bathyal to abyssal lithotectonic assemblages such as reliable and thick turbidite sequence, radiolarian-bearing chert and ophiolitic mélange.

In the central SCB, namely the Nanling and Xuefengshan areas, the stratigraphic sequences are similar to those of the eastern SCB. However, the Indosinian granitic magmatism is more pervasive than in the eastern SCB. Contrary to the case of the eastern SCB, the kinematic indicators for ductile folding and thrusting suggest here a top-to-the-northwest sense of movement.

In the western SCB, the Indosinian regional-scale unconformity, folding and thrusting are the same as for the eastern and central parts of the SCB. Contrary to the lithotectonic assemblages of the eastern and central parts of the SCB, 3-10-km-thick turbidite and ophiolitic rocks are widely distributed in the western SCB. Early-Middle Triassic volcanites and granites extensively occur along the Deqin-Weixi-Jinghong zone in western Yunnan. These geological facts suggest that Late Permian to Early Triassic subduction and collision took place along the Changning-Menglian suture zone in the western SCB.

Thus, it is concluded that the eastern SCB was far from the Indosinian subduction and collision zone, but the structure of the western SCB should be related to the collision between Indochina and the SCB. The folding, thrusting, and granitic plutonism in the eastern and central SCB is due to intracontinental tectonics.

\subsection{Geodynamics of the SCB during the Indosinian period}

It is well acknowledged that during the Late Permian-Early Triassic, an important deformation took place between South China and Indosinian blocks along the Song $\mathrm{Ma}-$ Menglian suture [22]. This event not only induced the closure of the Palaeo-Tethys Ocean, but it can be also responsible for the development of the intracontinental tectonics characterized by folding and thrusting and by a granitic magmatism in the SCB. The western part of the SCB, which is close to the Song Ma-Menglian suture, displays most of the features of a collision belt, namely ophiolites, deep-sea turbidites with submarine volcanic rocks and ductile flat-lying deformation. In western Yunnan, the calc-alkaline basalt-andesite-dacite series yielded zircon U-Pb SHRIMP ages of 215-250 Ma, which are in agreement with the existence of an Early-Middle Triassic active continental margin [3] and [36]. 
During the Permian, the Qiantang-Sibumasu Block was split from Gondwana. This continental block drifted southward during the Late Permian and the Early Triassic, and collided with Indochina, which was already welded with SCB, and, during the Early-Middle Triassic collision of the Sibumasu with Indochina, the Song Ma suture was reactivated as a dextral wrench fault [1]. The top-to-the-north, or northwest, folding-and-thrusting tectonics observed in the western SCB, in the Yunnan-Guizhou-Guangxi areas, and in the Xuefengshan in central SCB can be tentatively interpreted as a remote effect of the QiantangSibumasu collision.

The northern boundary of the SCB corresponds to the Qinling-Dabie orogen (Fig. 1). Although it is widely accepted that the Qinling-Dabie belt formed by the collision of SCB with the North China Block, the timing of collision remains disputed. Nevertheless, all authors agree that an Early Triassic event took place there (e.g., [7], [12], [31] and [32]]). The northward underthrusting of the SCB beneath the North China Block was responsible for the development of a several tenth of kilometre-scale south-directed décollement of the Palaeozoic series of the SCB. From southeastern Hubei to northern Jiangxi, in the central and eastern parts of the SCB, thrust faults and east-west-trending folds widely develop in response to the northward continental subduction of the SCB, giving rise to domes and antiformal stacks [5], [7] and [27]. Some S-type granites also emplaced in the Jiulingshan and Wugongshan at the same time [5] and [48], suggesting that the basement, which was also involved in this event, is significant. These features are sealed by a Late Triassic regional unconformity. Thus, intracontinental tectonics appears as the best explanation for the Early Mesozoic tectonic and magmatic events in the eastern and central part of the SCB.

\section{Conclusions}

Some new evidences of stratigraphic sequence, geochronological data of ophiolite and granite suggest that no Late Permian-Early Triassic ocean existed in the eastern and central parts of the SCB.

The study of facies sequences reveals that, during the Late Palaeozoic and the Early Mesozoic, the eastern and central parts of the SCB were in a shallow-sea/littoral-sea environment, without any development of volcanic rocks or deep-sea turbidites. Three coalbearing layers and six land-facies-plants-bearing strata in this interval argue against the hypothesis of an ocean basin in the eastern and central parts of the SCB. Deep-water deposits of chert and turbidite and a submarine arc-type volcanism took place only in the western part of the SCB, in Yunnan, i.e. close to the Indosinian suture.

The ages of three ophiolitic zones in the eastern SCB reveal a migration trend of ancient oceanic crust, from the northwest (930-1030 Ma for the Dexing-Shexian zone) toward the southeast (830-860 Ma for the Shaoxing-Jiangshan and Zhenghe-Dapu zones). In addition, a rifting event (800-820 Ma) was documented by subalkaline basalt and rhyolite in the Zhenghe-Dapu fault zone.

Geological and geochronological studies of the ophiolitic mélanges in the eastern SCB demonstrated that they formed in the Neoproterozoic and not during the Permian or the Triassic. The sedimentary rocks associated with these Neoproterozoic ophiolites only contain Proterozoic acritarchs, but no Late Palaeozoic radiolaria. 
Most of the Early Mesozoic granitoids (245-210 Ma) related to the Indosinian event belong to the peraluminous S-type. The genesis of these granitoids is likely related to the upwelling of asthenosphere.

The tectonic and magmatism features of the eastern and central SCB during the Early-Middle Triassic can be interpreted as an intracontinental response to the Indosinian collision that developed in the western part of the SCB.

\section{Acknowledgements}

We are grateful to professors Wang Dezi and Claude Lepvrier for their valuable helps. Professors B. Xu, Y.J. Wang and S.Y. Jiang are thanked for their earnest checking of this revised manuscript for English grammar, sentence structures and constructive suggestions that significantly improved the manuscript. This study was financially supported by the National Natural Science Foundation of China (grants Nos. 40634022, 40221301, 4013201, and 40572118) and the Ministry of Education in China (grants Nos. 306007 and 20060284008).

\section{References}

[1] A. Carter, D. Roques, C. Bristow and Understanding, Mesozoic accretion in Southeast Indosinian: Significance of Triassic thermotectonism (Indosinian orogeny) in Vietnam, Geology 29 (2001), pp. 211-214.

[2] J.F. Chen, K.A. Foland, F.M. Xing and T.X. Zhou, Magmatism along the Southeast margin of the Yangzi block: Precambrian collision of the Yangzi and Cathaysia blocks of China, Geology 19 (1991), pp. 815-818.

[3] B.L. Cong, G.Y. Wu and Q. Zhang, The petro-tectonic evolution of the paleo-Tethys zone in the western Yunnan, China, Sci. China B 23 (1994), pp. 1201-1207.

[4] J. Deprat, Étude des plissements et des zones d'écrasement de la moyenne et de la basse rivière Noire, Mem. Serv. geol. Indochine 3 (1914), pp. 1-59.

[5] M. Faure, Y. Sun, L.S. Shu, P. Monie and J. Charvet, Extensional tectonics within a subduction-type orogen. The case study of the Wugongshan dome (Jiangxi Province, southeastern China), Tectonophysics 263 (1996), pp. 77-106.

[6] M. Faure, W. Lin, L.S. Shu, Y. Sun and U. Schärer, Tectonics of the Dabieshan (eastern China) and possible exhumation mechanism of ultra high-pressure rocks, Terra Nova 11 (1999), pp. 251-258.

[7] M. Faure, W. Lin and Y. Sun, Doming in the southern foreland of the Dabieshan (Yangtse block, China), Terra Nova 10 (1998), pp. 307-311.

[8] J. Fromaget, Sur la structure des lndosinides, C. R. Acad. Sci. Paris 195 (1932), pp. 1-53. 
[9] FBGMR: Fujian Bureau of Geology and Mineral Resources, Regional geology of Fujian Province, Geol. Publ. House, Beijing, China (1985) (in Chinese, with English abstract).

[10] S.A. Gilder, J. Gill, R.S. Coe, X.X. Zhao, Z.W. Liu and G.X. Wang, Isotopic and paleomagnetic constraints on the Mesozoic tectonic evolution of South China, J. Geophys. Res. 107 (B7) (1996), pp. 16137-16154.

[11] P.C. Goodel, S. Gilder and X. Fang, A preliminary description of the Gan-Hang failed rift, southeastern China, Tectonophysics 197 (1991), pp. 245-255.

[12] L. Hacker, L. Ratsbacher, T. Webb, D. Ireland and D. Walker, Suwen, U/Pb zircon ages constrain the architecture of the ultrahigh-pressure Qinling-Dabie orogen, China, Earth Planet. Sci. Lett. 161 (1998), pp. 215-230.

[13] HBGMR: Hunan Bureau of Geology and Mineral Resources, Regional geology of Jiangxi Province, Geol. Publ. House, Beijing, China (1987) 650 p. (in Chinese, with English abstract).

[14] Q.L. Hou, P.J. Li and J.L. Li, Foreland fold-thrust belt in southwestern Fujian China, Geol. Publ. House, Beijing, China (1995) 105 p. (in Chinese, with English abstract).

[15] K.J. Hsu, S. Sun, J.L. Li, H.H. Chen and A.M.X. Sengör, Mesozoic overthrust tectonics in South China, Geology 16 (1988), pp. 418-421.

[16] T.K. Huang, On major tectonic forms of China, Am. Assoc. Pet. Geol. Mem. (1945), pp. $1-165$.

[17] JBGMR (Jiangxi Bureau of Geology and Mineral Resources), Regional geology of Jiangxi Province, Geol. Publ. House, Beijing, China (1984) (in Chinese, with English abstract).

[18] X.S. Kong, Z.F. Li, C.G. Feng, M.G. Gu and J.P. Ma, The Precambrian geology of Chencai region in Zhejiang Province, Geol. Publ. House, Beijing, China (1995) 136 p. (in Chinese, with English abstract).

[19] C.Y. Lan, S.L. Chung, J.S. Shen and S. Jiun, Geochemical and Sr-Nd isotopic characteristics of granitic rocks from northern Vietnam, J. Asian Earth Sci. 18 (2000), pp. 267-280.

[20] Q.Y. Lao, Tectonostratigraphic terrane in the East China Sea, In: Y. Shi, H. Lu, R. Ma, Y Sun (Eds.), Symposium of the researches on modern geology (II), Publishing House of Nanjing University, Nanjing, China, 1994, pp. 81-91.

[21] C. Lepvrier, H. Maluski and V. Nguyen, ${ }^{40} \mathrm{Ar} /{ }^{39} \mathrm{Ar}$ Indosinian age of NW-trending dextral shear zones within the Truong Son belt (Vietnam): Cretaceous to Cenozoic overprinting, Tectonophysics 283 (1997), pp. 105-127.

[22] C. Lepvrier et al., The Early Triassic Indosinian orogeny in Vietnam (Truong Son belt) and Kontum massif); implications for the geodynamic evolution of Indochina, Tectonophysics 393 (2004), pp. 87-118. 
[23] W.X. Li, X.H. Li and Z.X. Li, Neoproterozoic bimodal magmatism in the Cathaysia Block of South China and its tectonic significance, Precambr. Res. 136 (2005), pp. 51-66.

[24] X.H. Li, G.Q. Zhou, J.X. Zhao, C.M. Fanning and W. Compston, SHRIMP ion microprobe zircon $\mathrm{U}-\mathrm{Pb}$ age and $\mathrm{Sm}-\mathrm{Nd}$ isotopic characteristics of the NE Jiangxi ophiolite and its tectonic implications, Chin. J. Geochem. 13 (1994), pp. 317-325.

[25] X.H. Li, Z.X. Li, W.X. Li and Y.J. Wang, Initiation of the Indosinian Orogeny in South China: Evidence for a Permian Magmatic Arc on Hainan Island, J. Geol. 114 (2006), pp. 341353.

[26] Z.X. Li and X.H. Li, Formation of the 1300-km-wide intracontinental orogen and postorogenic magmatic province in Mesozoic South China: a flat-slab subduction model, Geology 35 (2007), pp. 179-182.

[27] W. Lin, M. Faure, Y. Sun and L. Shu, Compression to extension switch during the Early Triassic orogeny of E.China: the case study of the Jiulingshan massif in the southern foreland of the Dabieshan, J. Asian Earth Sci. 20 (2001), pp. 31-43.

[28] B.G. Liu, G.C. Zheng, S.M. Chen and H.F. Tang, The breakup of the Songmuwu Group in western Zhejiang: evidence from isotope dating, Geol. Rev. 41 (1995), pp. 457-462.

[29] C. Lo and T.H. Yui, ${ }^{40} \mathrm{Ar} /{ }^{39} \mathrm{Ar}$ dating of high-pressure rocks in the Tananao basement complex, Taiwan, J. Geol. Soc. 39 (1996), pp. 13-30 (China).

[30] H. Maluski, C. Lepvrier and L. Jolivet, Ar-Ar and fission-track ages in the Song Chay Massif: Early Triassic and Cenozoic tectonics in northern Vietnam, J. Asian Earth Sci. 19 (2001), pp. 233-248.

[31] M. Mattauer, P. Matte, J. Malavieille, P. Tapponnier, H. Maluski, Z. Xu, Y. Lu and Y. Tang, Tectonics of the Qinling Belt: build-up and evolution of eastern Asia, Nature 317 (1985), pp. 496-500.

[32] M. Mattauer, P. Matte, H. Maluski, Z. Xu, Q. Zhang and Y. Wang, La limite Chine du Nord-Chine du Sud au Paléozoïque et au Trias: Nouvelles données structurales et radiométriques dans le massif du Dabieshan (chaîne des Qinling), C. R. Acad. Sci., Paris Ser. II 312 (1991), pp. 1227-1233.

[33] I. Metcalfe, Gondwana and dispersion, Asian accretion and evolution of eastern Tethys, Aust. J. Earth Sci. 43 (1996), pp. 605-623.

[34] Nam Tran Ngoc, Thermotectonic events from Early Proterozoic to Miocene in the Indochina craton: implication of K-Ar ages in Vietnam, J. Asian Earth Sci. 16 (1998), pp. 475-484.

[35] B.X. Peng, Y.J. Wang, W.M. Fan, T.P. Peng and X.Q. Liang, LA-ICPMS zircon U-Pb dating for three Indosinian granitic plutons from central Hunan and western Guangdong Provinces and its petrogenetic implications, Acta Geol. Sin. 80 (2006), pp. 660-669. 
[36] T.P. Peng, Y.J. Wang, W.M. Fan, D.Y. Liu, Y.R. Shi and L.C. Miao, The SHRIMP zircon $\mathrm{U}-\mathrm{Pb}$ geochronology of the Early Mesozoic felsic igneous rocks from the southern Lancangjiang and its tectonic implications, Sci. China D 49 (2006), pp. 1032-1042.

[37] A.E. Pirajno-Dounce and L. Babas, Gold and silver metallogeny of the South China fold belt: a consequence of multiple mineralization events , Ore Geol. Rev. 20 (2002), pp. 109126.

[38] J. Rodgers, Comment on "Mesozoic overthrust tectonics in South China", Geology 17 (1989), pp. 671-672.

[39] D.B. Rowley, A.M. Ziegler and N. Gyou, Comment on "Mesozoic overthrust tectonics in South China", Geology 17 (1989), pp. 384-386.

[40] J.G. Shao, S.M. Peng and S.B. Peng, ${ }^{40} \mathrm{Ar} /{ }^{36} \mathrm{Ar}-{ }^{39} \mathrm{Ar} /{ }^{36} \mathrm{Ar}$ isochrone dating for peripheral faults of Yunkai Massif, Guangdong Geol. 10 (1995), pp. 34-40.

[41] L.S. Shu, Pre-Devonian Tectonic Evolution of South China: from Cathaysian Block to Caledonian Period Folded Orogenic Belt, Geol. J. China Univ. 12 (2006), pp. 418-431.

[42] L.S. Shu, G.Q. Zhou, Y.S. Shi and J. Yin, Study of the high pressure metamorphic blueschist and its Late Proterozoic age in the eastern Jiangnan belt, Chin. Sci. Bull. 39 (1994), pp. 1200-1204.

[43] L.S. Shu and J. Charvet, Kinematics and geochronology of the Proterozoic DongxiangShexian ductile shear zone: with HP metamorphism and ophiolitic melange (Jiangnan region, South China), Tectonophysics 267 (1996), pp. 291-302.

[44] L.S. Shu, Y. Sun, D.C. Wang, M. Faure, J. Charvet and P. Monié, Mesozoic doming extentional tectonics of Wugongshan, South China, Sci. China D 41 (1998), pp. 601-608.

[45] L.S. Shu, M. Faure, S.Y. Jiang, Q. Yang and .Y.J. Wang, SHRIMP zircon U-Pb age, litho- and biostratigraphic analyses of the Huaiyu Domain in South China- Evidence for a Neoproterozoic orogen, not Late Paleozoic-Early Mesozoic collision, Episodes 29 (2006), pp. 244-252.

[46] T. Sun, X.M. Zhou, P.R. Chen, H.M. Li, H.Y. Zhou, Z.C. Wang and W.Z. Shen, Mesozoic strongly peraluminous granites from eastern Nanling Mountains Range, southern China: Petrogenesis and implications for tectonics, Sci. China D 48 (2005), pp. 164-174.

[47] B. Wang and L.S. Shu, Notes on Late Paleozoic radiolarians of northeastern Jiangxi Province, Geol. Rev. 47 (2001), pp. 337-344.

[48] D.Z. Wang, L.S. Shu, M. Faure and W.Z. Sheng, Mesozoic magmatism and granitic dome in the Wugongshan massif, Jiangxi Province and their genetical relationship to the tectonic events in Southeast China, Tectonophysics 339 (2001), pp. 259-277.

[49] M. Wang and L.S. Shu, Petrological geochemical featrures of Neoproterozoic ophiolite mélange in Wuyishan area, Geol. J. China Univ. 34 (2007), pp. 572-583. 
[50] Q. Wang, J.W. Li, P. Jian, Z.H. Zhao, X.L. Xiong, Z.W. Bao, J.F. Xü, C.F. Li and J.L. Ma, Alkaline syenites in eastern Cathaysia (South China): Link to Permian-Triassic transtension, Earth Planet. Sci. Lett. 230 (2005), pp. 339-354.

[51] Y.J. Wang, W.M. Fan and P. Guo, Geochemistry of Early Mesozoic potassium-rich dioritic-granodioritic intrusions in southeastern Hunan Province, South China: petrogenesis and tectonic implications, Geochem. J. 37 (2003), pp. 427-448.

[52] Y.J. Wang, W.M. Fan, F. Guo, T.P. Peng and C.W. Li, Geochemistry of Mesozoic mafic rocks adjacent to the Chenzhou-Wulin fault, South China: implications for the lithospheric boundary between the Yangtze and the Cathaysia blocks, Int. Geol. Rev. 45 (2003), pp. 263286.

[53] Y.J. Wang, Y.H. Zhang, W.M. Fan and T.P. Peng, Structural signatures and ${ }^{40} \mathrm{Ar} /{ }^{39} \mathrm{Ar}$ geochronology of the Indosinian Xuefengshan tectonic belt, South China Block, J. Struct. Geol. 27 (2005), pp. 985-998.

[54] Y.J. Wang, Q. Yang, L.M. Yin, L.S. Shu, F.S. Lou and B. Wang, The putative "radiolarian cherts" from ophiolitic and metamorphic complexes in northeastern Jiangxi: a reexamination, Geol. J. China Univ. 12 (2006), pp. 98-105.

[55] Y.J. Wang, W.M. Fan, M. Sun, X.Q. Liang, Y.H. Zhang and T.P. Peng, Geochronological, geochemical and geothermal constraints on petrogenesis of the Indosinian peraluminous granites in the South China Block: A case study in the Hunan Province, Lithos 96 (3-4) (2007), pp. 475-502.

[56] W.J. Xiao and H.Q. He, Early Mesozoic thrust tectonics of the Northwest Zhejiang region (Southeast China), Geol. Soc. Am. Bull. 117 (2005), pp. 1-17.

[57] B. Xu and G.S. Qiao, Sm-Nd isotopic age and tectonic setting of the Late Proterozoic ophiolites in northeastern Jiangxi Province, J. Nanjing Univ. (Earth Sci.) 3 (1989), pp. 108114.

[58] D.P. Yan, M.F. Zhou, M. Faure, H.L. Song, X.W. Wang and F.G. Malpas, A Mesozoic thin-skinned to thick-skinned multi-layer over-thrust system within the Yangtze Block (South China), Tectonophysics 361 (2003), pp. 239-254.

[59] Q. Yang, Y.J. Wang, L.M. Yin, L.S. Shu, F.S. Lou and B. Wang, On the age of the ophiolitic complexes in northeastern Jiangxi: a micropaleontological analysis, Acta Geol. Sin. 79 (2005), pp. 801-805.

[60] Z.Y. Yang, Z.S. Li, L.F. Qu, Z.M. Lu, H.Q. Zhou, T.S. Zhou, G.F. Liu, B.P. Liu and R.T. Wu, The Triassic of China, Acta Geol. Sin. 56 (1982), pp. 1-20.

[61] A. Yao, Y. Ezaki, K. Kuwahara, W. Hao and J.b. Liu, The Devonian-Triassic of South China: Natures of the end-Permian mass extinction and origins of the Japanese Islands, Topics Paleontol. 2 (2001), pp. 45-52. 
[62] YBGMR: Yunnan Bureau of Geology and Mineral Resources, Regional geology of Yunnan Province, Geol. Publ. House, Beijing, China (1987) (in Chinese, with English abstract).

[63] ZBGMR (Zhejiang Bureau of Geology and Mineral Resources), Stratigraphy (lithostrata) of Zhejiang Province, China University of Geosciences Press, Beijing, China (1996) (in Chinese, with English abstract).

[64] C.H. Zhao, K.Z. He, X.X. Mo, D.Q. Tai, D.L. Ye, N. Ye, P.Y. Lin, X.M. Bi, B.R. Zheng and Q.L. Feng, The discovery of the Late Paleozoic radiolarian chert in the ophiolitic mélange along the NW Jiangxi fault and its implications, Chin. Sci. Bull. 40 (1995), pp. 2161-2163.

[65] D.L. Zhong, G.Y. Wu and J.Q. Ju, The Ophiolite discovered in the southeastern Yunnan, Chin. Sci. Bull. 43 (1998), pp. 1365-1370.

[66] X.M. Zhou, H.B. Zhou, J.D. Yang and Y.X. Wang, Sm-Nd isochron age of the ophiolite suite in Shexian County, Anhui Province and its geological significance, Chin. Sci. Bull. 35 (1989), pp. 208-212.

[67] X.M. Zhou and Y.H. Zhu, Magma mixing in the Jiang-Shao fault zone and the Precambrian geology of both side of the Jiang-Shao zone, Sci. China B 22 (1992), pp. 298303.

[68] X.M. Zhou, T. Sun, W.Z. Shen, L.S. Shu and Y.L. Niu, Petrogenesis of Mesozoic granitoids and volcanic rocks in South China: A response to tectonic evolution, Episodes 29 (2006), pp. 26-33. 


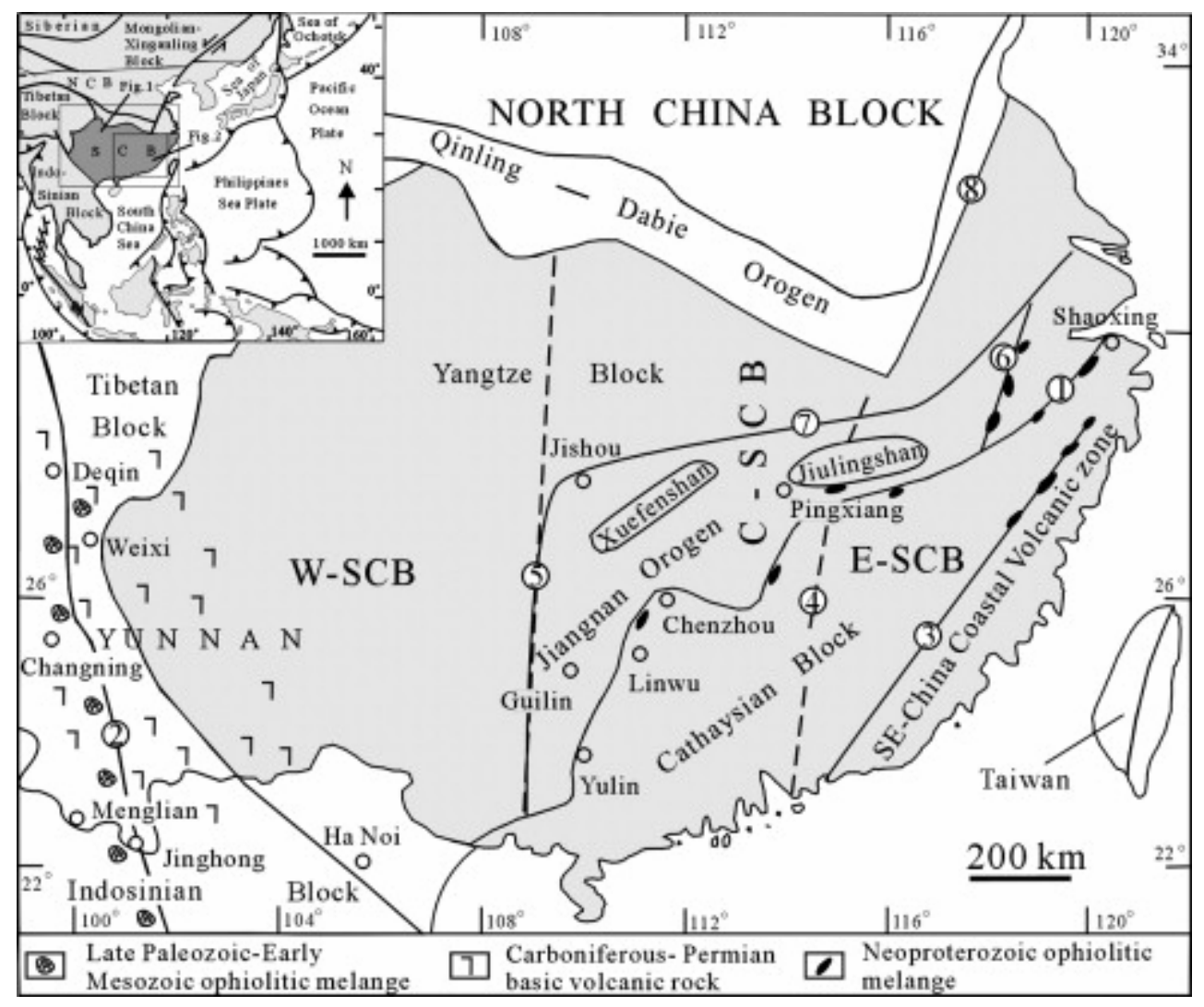

Fig. 1. Simplified tectonic map of the South China Block (SCB), showing its importance in the Southeast Asian region. E-SCB, the eastern part of SCB; C-SCB, the central part of SCB; E-SCB, the western part of SCB; , Shaoxing-Jiangshan-Pingxiang-Yulin Neoproterozoic ophiolitic zone; , Song Ma-Menglian Early Mesozoic ophiolitic zone; , Zhenghe-Dapu Neoproterozoic ophiolitic zone; , Ganjiang fault; , Jishou-Guilin fault; , Dexing-Shexian Neoproterozoic ophiolitic zone; , the NW-boundary of Jiangnan Neoproterozoic orogenic belt, ,Tan-Lu fault.

Fig. 1. Carte tectonique simplifiée du bloc de Chine du Sud (BCS), montrant son importance au sein de l'Asie du Sud-Est. W-SCB, partie occidentale de SCB ; C-SCB, partie centrale de $\mathrm{SCB}$; E-SCB, partie orientale de SCB ; , zone ophiolitique néoprotérozoïque de ShaoxingJiangshan-Pingxiang-Yulin; , zone ophiolitique du début du Mésozoïque de Song MaMenglian ; , zone ophiolitique néoprotérozoïque de Zhenghe-Dapu ; , faille de Ganjiang ; , faille de Jishou-Guilin ; , zone ophiolitique néoprotérozoïque de Dexing-Shexian ; , la frontière nord-ouest de la ceinture orogénique néoprotérozoïque de Jiangnan; , faille de Tan-Lu. 

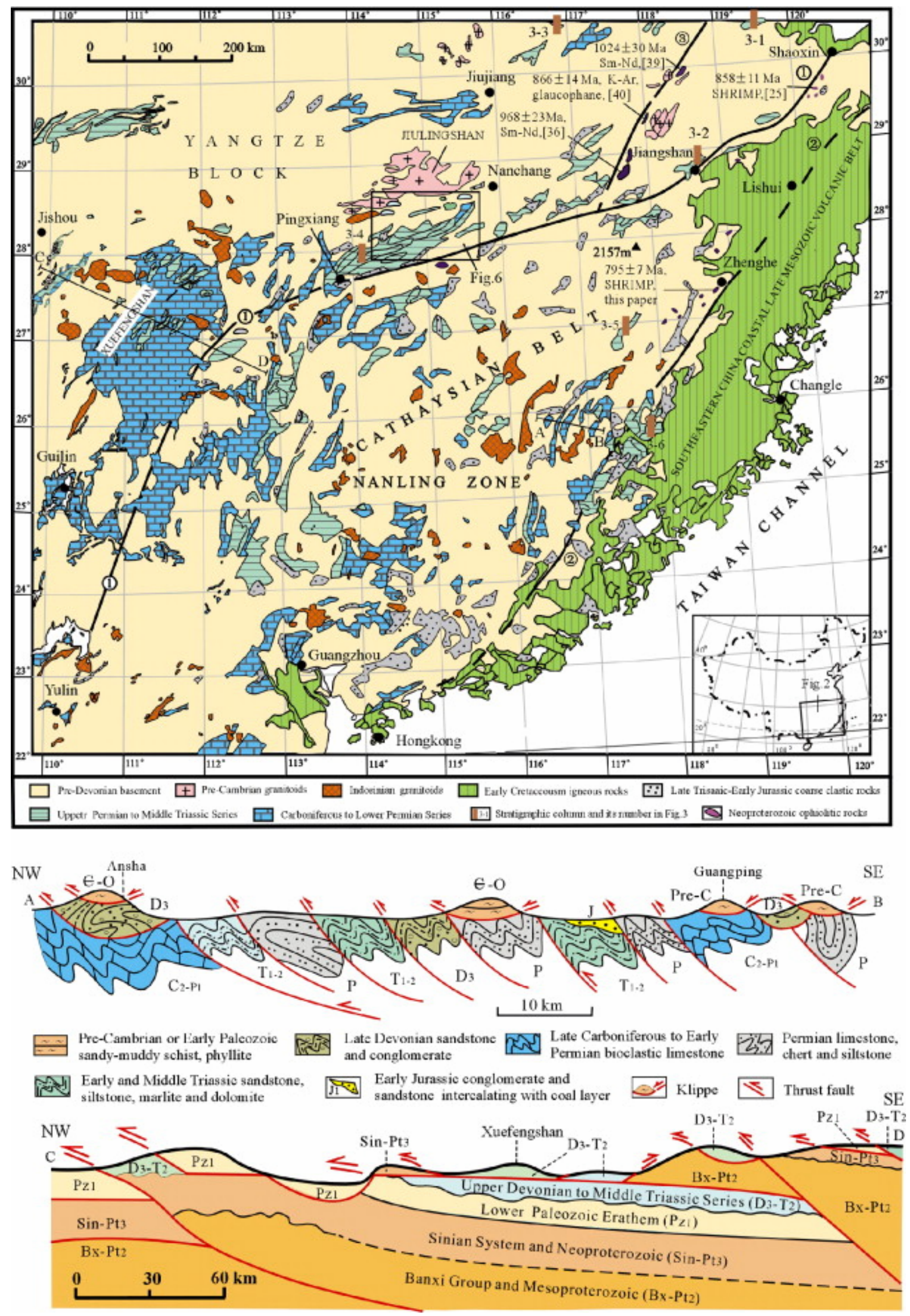
Fig. 2. The geological map with sections A, B and C, D of the eastern and central parts of the $\mathrm{SCB}$, showing the distribution of the Late Palaeozoic to Early Mesozoic strata and the Indosinian granitic plutons (modified from [6], [8], [17], [63] and [67]). Geological section C, D is modified from [13] and [53]. , Shaoxing-Jiangshan-Pingxiang fault zone; , ZhengheDapu fault zone; , Dexing-Shexian fault zone.

Fig. 2. Carte géologique, avec emplacements des coupes $\mathbf{A}, \mathbf{B}$ et $\mathbf{C}, \mathbf{D}$ des parties orientale et centrale du BCS, montrant la distribution de la couverture de la fin du Paléozoïque et du début du Mésozoïque et les plutons granitiques indosiniens (modifié d'après [6], [8], [17] and [67]). La coupe géologique $\mathbf{C}, \mathbf{D}$ est modifiée d'après [13] and [53]. , zone de faille de ShaoxingJiangshan-Pingxiang; , zone de faille de Zhenghe-Dapu ; , zone de faille de DexingShexian.

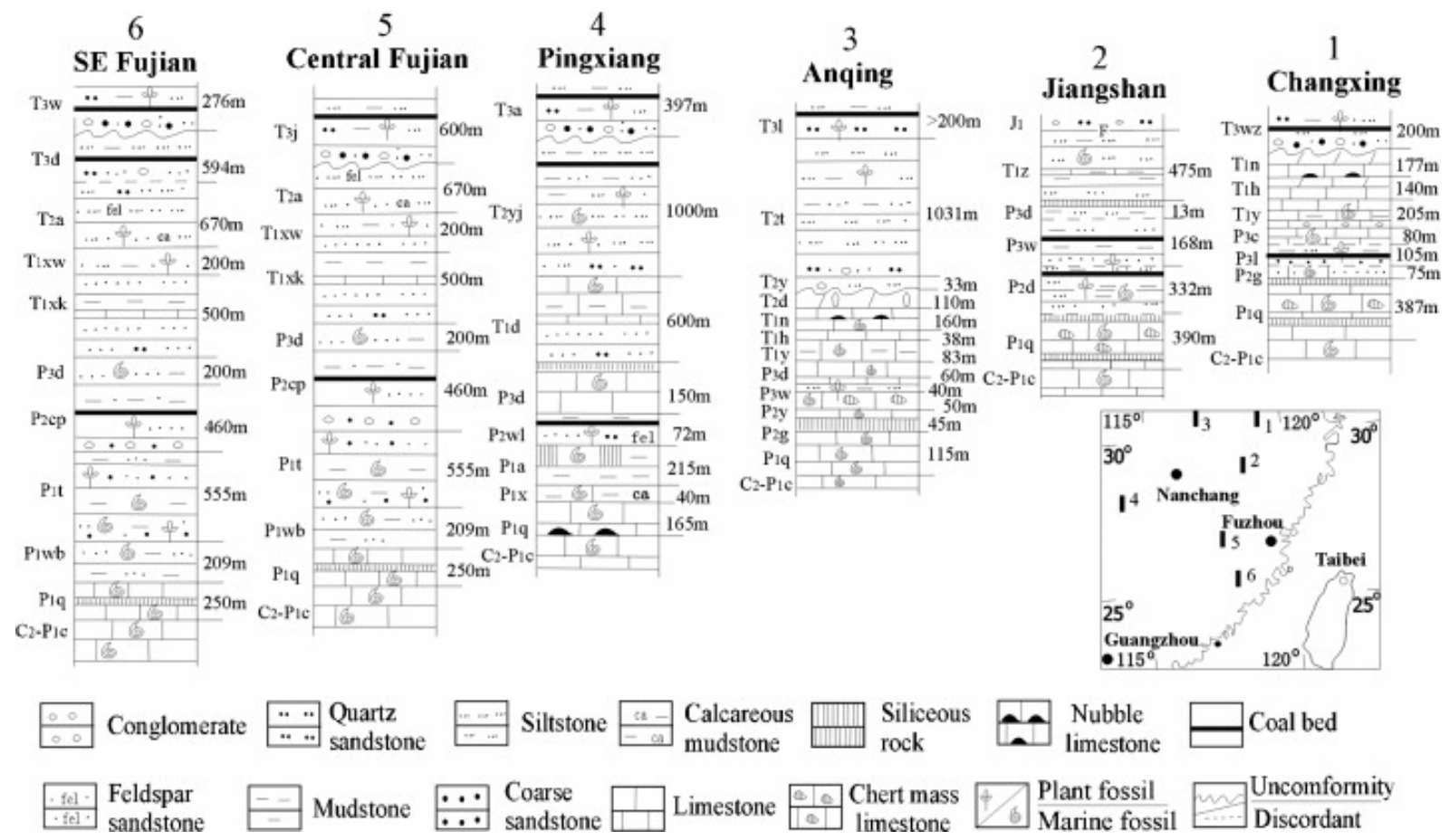

Fig. 3. Six stratigraphic columns, from the Late Carboniferous to the Late Triassic, of the eastern-central SCB, showing an environment of shallow sea-littoral sea (modified from [45]). Symbols of strata: $\mathbf{J}_{\mathbf{1}}$, Lower Jurassic Series; $\mathbf{T}_{\mathbf{3}}$, Upper Triassic Series; $\mathbf{T}_{\mathbf{2}}$, Middle Triassic Series; $\mathbf{T}_{\mathbf{1}}$, Lower Triassic Series; $\mathbf{P}_{\mathbf{3}}$, Upper Permian Series; $\mathbf{P}_{\mathbf{2}}$, Middle Permian Series; $\mathbf{P}_{\mathbf{1}}$, Lower Permian Series; $\mathbf{C}_{\mathbf{2}}-\mathbf{P}_{\mathbf{1}}$, Upper Carboniferous to Lower Permian Series. $\mathbf{T}_{\mathbf{3}} \mathbf{a}$, Anyuan Formation; $\mathbf{T}_{3} \mathbf{d}$, Dakeng Formation; $\mathbf{T}_{3} \mathbf{l}$, Lalijian Formation; $\mathbf{T}_{\mathbf{3}} \mathbf{j}$, Jiaokeng Formation; $\mathbf{T}_{3} \mathbf{w}$, Wenbinshan Formation; $\mathbf{T}_{3} \mathbf{w z}$, Wuzhao Formation; $\mathbf{T}_{\mathbf{2}} \mathbf{a}$, Anren Formation; $\mathbf{T}_{\mathbf{2}} \mathbf{d}$, Dong maanshan Formation; $\mathbf{T}_{2} \mathbf{t}$, Tongtoujian Formation; $\mathbf{T}_{\mathbf{2}} \mathbf{y} \mathbf{j}$, Yangjia Group; $\mathbf{T}_{2} \mathbf{y}$, Yueshan Formation; $\mathbf{T}_{\mathbf{1}} \mathbf{d}$, Daye Formation; $\mathbf{T}_{\mathbf{1}} \mathbf{h}$, Helongshan Formation; $\mathbf{T}_{\mathbf{1}} \mathbf{n}$, Nanlinhu Formation; $\mathbf{T}_{\mathbf{1}} \mathbf{x w}$, Xiwei Formation; $\mathbf{T}_{\mathbf{1}} \mathbf{x k}$, Xikoi Formation; $\mathbf{T}_{\mathbf{1}} \mathbf{y}$, Yinkeng Formation; $\mathbf{T}_{\mathbf{1}} \mathbf{z}$, Zhengtang Formation; $\mathbf{P}_{3} \mathbf{C}$, Changhsing Formation; $\mathbf{P}_{3} \mathbf{d}$, Dalong Formation; $\mathbf{P}_{\mathbf{3}} \mathbf{l}$, Longtan Formation; $\mathbf{P}_{\mathbf{3}} \mathbf{l}$, Loping Formation; $\mathbf{P}_{3} \mathbf{W}$, Wujiaping Formation; $\mathbf{P}_{\mathbf{2}} \mathbf{g}$, Gufeng Formation; $\mathbf{P}_{\mathbf{2}} \mathbf{c p}$, Cuipingshan Formation; $\mathbf{P}_{\mathbf{2}} \mathbf{w l}$, Wulinshan Formation; $\mathbf{P}_{\mathbf{1}} \mathbf{a}$, Anzhou Formation; $\mathbf{P}_{\mathbf{1}} \mathbf{d}$, Dingjiashan Formation; $\mathbf{P}_{\mathbf{1}} \mathbf{q}$, Qixia Formation; $\mathbf{P}_{\mathbf{1}} \mathbf{s}$, Shizixing Formation; $\mathbf{P}_{\mathbf{1}} \mathbf{t}$, Tongziyan Formation; $\mathbf{P}_{\mathbf{1}} \mathbf{w b}$, Wenbishan Formation; $\mathbf{P}_{\mathbf{1}} \mathbf{w}$, Wuxue Formation; $\mathbf{P}_{\mathbf{1}} \mathbf{x}$, Xiaojiangbian Formation; $\mathbf{P}_{\mathbf{1}} \mathbf{y}$, Yinping Formation; $\mathbf{C}_{2}-\mathbf{P}_{\mathbf{1}} \mathbf{c}$, Chuanshan Formation. 
Fig. 3. Colonnes stratigraphiques de la fin du Carbonifère au Trias terminal dans la partie centre-orientale du BSC, traduisant un environnement de mer peu profonde ou de littoral (d'après [45], modifié). Symboles stratigraphiques : $\mathbf{J}_{\mathbf{1}}$, séries du Jurassique inférieur ; $\mathbf{T}_{\mathbf{3}}$, séries du Trias supérieur; $\mathbf{T}_{2}$, séries du Trias moyen; $\mathbf{T}_{\mathbf{1}}$, séries du Trias inférieur $; \mathbf{P}_{3}$, séries du Permien supérieur ; $\mathbf{P}_{\mathbf{2}}$, séries du Permien moyen ; $\mathbf{P}_{\mathbf{1}}$, séries du Permien inférieur $; \mathbf{C}_{\mathbf{2}}-\mathbf{P}_{\mathbf{1}}$, séries du Carbonifère supérieur au Permien inférieur. $\mathbf{T}_{3} \mathbf{a}$, formation Anyuan; $\mathbf{T}_{3} \mathbf{d}$, formation Dakeng ; $\mathbf{T}_{\mathbf{3}} \mathbf{l}$, formation Lalijian; $\mathbf{T}_{\mathbf{3}} \mathbf{j}$, formation Jiaokeng ; $\mathbf{T}_{\mathbf{3}} \mathbf{W}$, formation Wenbinshan ; $\mathbf{T}_{3} \mathbf{W Z}$, formation Wuzhao ; $\mathbf{T}_{2} \mathbf{a}$, formation Anren; $\mathbf{T}_{2} \mathbf{d}$, formation Dong maanshan ; $\mathbf{T}_{2} \mathbf{t}$, formation Tongtoujian; $\mathbf{T}_{\mathbf{2}} \mathbf{y j}$, groupe Yangjia ; $\mathbf{T}_{\mathbf{2}} \mathbf{y}$, formation Yueshan $; \mathbf{T}_{\mathbf{1}} \mathbf{d}$, formation Daye ; $\mathbf{T}_{\mathbf{1}} \mathbf{h}$, formation Helongshan; $\mathbf{T}_{\mathbf{1}} \mathbf{n}$, formation Nanlinhu ; $\mathbf{T}_{\mathbf{1}} \mathbf{X w}$, formation Xiwei ; $\mathbf{T}_{\mathbf{1}} \mathbf{x k}$, formation Xikoi ; $\mathbf{T}_{\mathbf{1}} \mathbf{y}$, formation Yinkeng ; $\mathbf{T}_{\mathbf{1}} \mathbf{z}$, formation Zhengtang $; \mathbf{P}_{\mathbf{3}} \mathbf{C}$, formation Changhsing $; \mathbf{P}_{3} \mathbf{d}$, formation Dalong ; $\mathrm{P}_{3}$ l, formation Longtan ; $\mathrm{P}_{3}$ l, formation Loping; $\mathbf{P}_{3} \mathbf{W}$, formation Wujiaping; $\mathbf{P}_{\mathbf{2}} \mathbf{g}$, formation Gufeng $; \mathbf{P}_{\mathbf{2}} \mathbf{C p}$, formation Cuipingshan $; \mathbf{P}_{\mathbf{2}} \mathbf{w l}$, formation Wulinshan; $\mathbf{P}_{\mathbf{1}} \mathbf{a}$, formation Anzhou $; \mathbf{P}_{\mathbf{1}} \mathbf{d}$, formation Dingjiashan $; \mathbf{P}_{\mathbf{1}} \mathbf{q}$, formation Qixia ; $\mathbf{P}_{\mathbf{1}} \mathbf{s}$, formation Shizixing ; $\mathbf{P}_{\mathbf{1}} \mathbf{t}$, formation Tongziyan $; \mathbf{P}_{\mathbf{1}} \mathbf{w b}$, formation Wenbishan ; $\mathbf{P}_{\mathbf{1}} \mathbf{w}$, formation Wuxue ; $\mathbf{P}_{\mathbf{1}} \mathbf{x}$, formation Xiaojiangbian $; \mathbf{P}_{\mathbf{1}} \mathbf{y}$, formation Yinping $; \mathbf{C}_{\mathbf{2}}-\mathbf{P}_{\mathbf{1}} \mathbf{c}$, formation Chuanshan. 


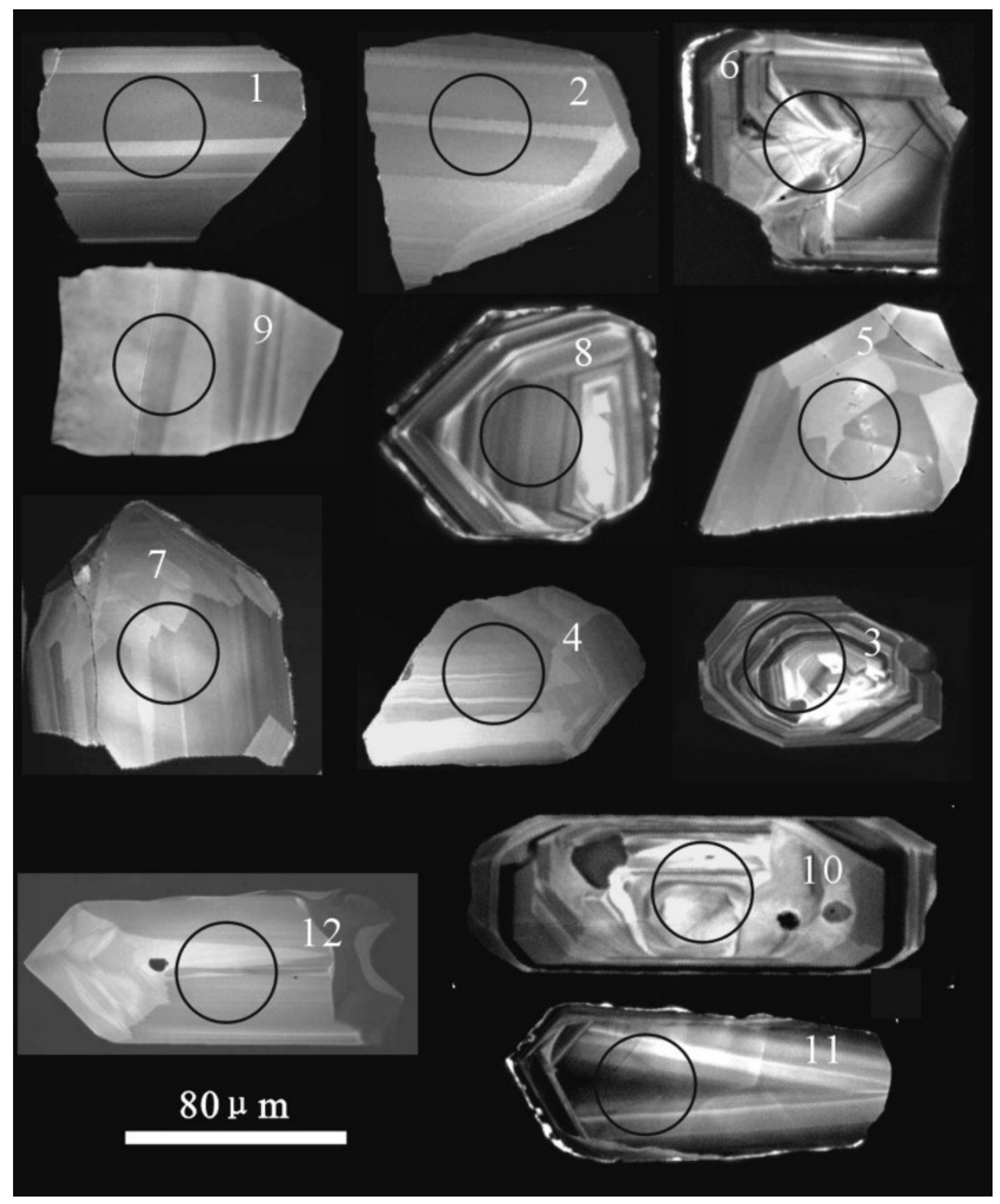

Fig. 4. Cathodoluminescence images of zircon grains from the basalt sample 452 of the Zhenghe-Dafu ophiolitic melange zone. Circles represent the analyzed spots.

Fig. 4. Images en cathodoluminescence de grains de zircon de l'échantillon de basalte 452, en provenance de la zone de mélange ophiolitique de Zhenghe-Dafu. 


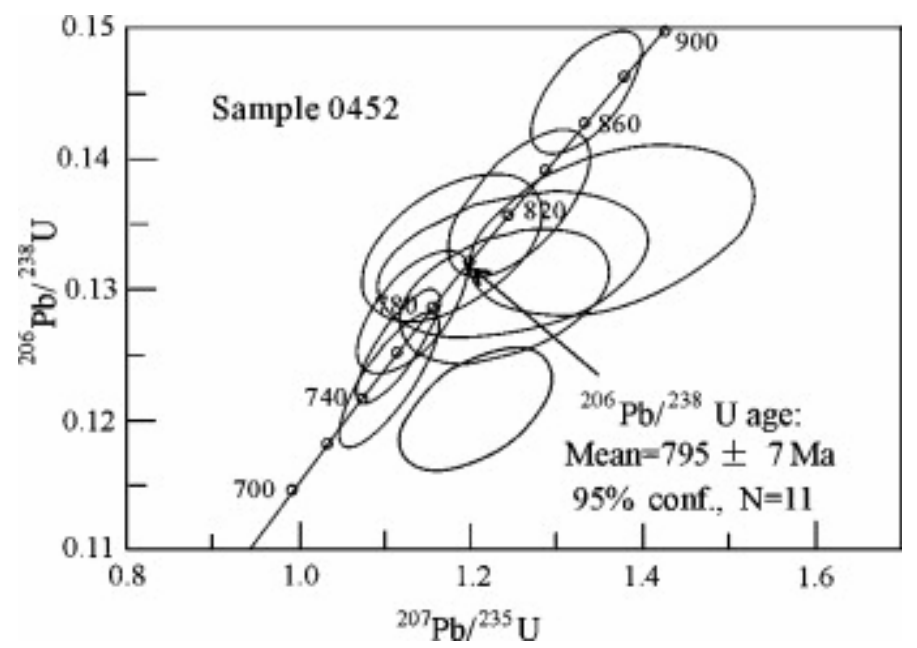

Fig. 5. SHRIMP U-Pb age on zircon grains from the Zhenghe ophiolitic basalt, sampled in the town of Zhenghe.

Fig. 5. Âge SHRIMP U-Pb sur grains de zircon dans le basalte ophiolitique de Zhenghe, échantillonné dans la ville de Zhenghe.

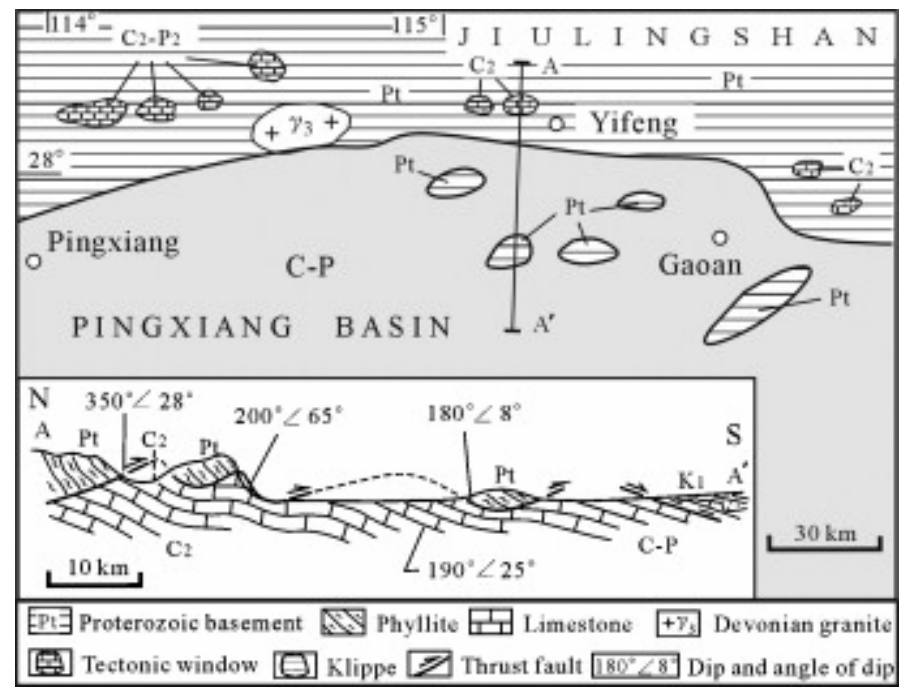

Fig. 6. Geological map, with section $\mathbf{A}-\mathbf{A}^{\prime}$, in the southern slope of the Jiulingshan showing a top-to-the-south thrusting deformation during the Indosinian period.

Fig. 6. Carte géologique, avec mention de la coupe $\mathbf{A}-\mathbf{A}^{\prime}$, du versant méridional du Jiulingshan, montrant une déformation cisaillante vers le sud au cours de la période indosinienne. 
Table 1. : Analytical data from SHRIMP zircon $\mathrm{U}-\mathrm{Pb}$ dating for the Cathaysian Ophiolitic basalt, Zhenghe area

Tableau 1. Données analytiques correspondant à la datation SHRIMP U-Pb sur zircon du basalte ophiolitique cathaysien de la région de Zhenghe

Common ${ }^{206} \mathrm{~Pb}(\%)$ means the percentage of ${ }^{206} \mathrm{~Pb}$ in common lead vs that in total lead, and weighted mean ${ }^{206} \mathrm{~Pb} /{ }^{238} \mathrm{U}$ ages with $1 \sigma$ error are in $95 \%$ confidence.

Notes infrapaginales : ${ }^{206} \mathrm{~Pb}(\%)$ commun signifie le pourcentage de ${ }^{206} \mathrm{~Pb}$ en plomb commun par rapport au plomb total, tandis que « weighted » signifie âges ${ }^{206} \mathrm{~Pb} /{ }^{238} \mathrm{U}$, avec une erreur de $1 \sigma$, 